\title{
THE USE OF EXERCISES AND ASSIGNMENTS THROUGH THE SCAFFOLDING METHOD IN THE DEVELOPMENT OF FORMS OF COMMUNICATION IN ENGLISH
}

\section{Gulnora Shakirdjanovna Azizova}

Senior Teacher, Department Of Uzbek And Foreign Languages National Institute Of Arts And Design Named After Kamoliddin Bekhzod, Uzbekistan

\section{ABSTRACT}

This article discusses the use of exercises and assignments through the scaffolding method in the development of communication types in English. Learning English language should take place in parallel with the discovery of new cultural realities, a new linguistic environment. English language is not just a set of new words and rules; it is a new world that allows you to master the language. In addition, it takes time for the study of the language to take place in this direction.

KEYWORDS: - Questions, collaboration, modeling, scaffolding strategy, higher education, graduate students, adaptation system, insufficient competence, both young specialists, scaffolding method, development, foreign language, cultural realities, linguistic environment.

\section{INTRODUCTION}

Scaffolding techniques are such as activating existing knowledge, prompting trainees about the best strategy for completing the task, using the "thinking out loud" tactic, speaking or verbalizing the process of thinking about the task after completing it, questions, collaboration, modeling, methods of stress reduction, practical help, etc. At the same time, practice shows that the scaffolding strategy is more appropriate in the system of higher education, especially undergraduates and graduate students, and in the adaptation system, as a rule, it is difficult to apply due to the insufficient competence of both young specialists and sometimes the mentors themselves.
Sometimes students turn to English language teacher with such a question. Before giving them, an answer and expressing their opinion, expert linguists and methodologists ask students to answer the following question: "What does learn English language mean to you?" The following story can often be found among the students' answers. Sometimes students turn to English language teacher with such a question. Before giving them, an answer and expressing their opinion, expert linguists and methodologists ask students to answer the following question: "What does learn English language mean to you?" The following story can often be found among the students' answers. A student studying English language online said that she/he was looking for group classes in a language school, but also wanted to study with a teacher individually. 
CURRENT RESEARCH JOURNAL OF PHILOLOGICAL SCIENCES 2(10): 36-

40, October 2021

DOI: https://doi.org/10.37547/philological-crjps-02-10-08

ISSN 2767-3758

(C)2021 Master Journals

Crossref do

gil Google

Accepted26 ${ }^{\text {th }}$ October, 2021 \& Published $31^{\text {th }}$ October, 2021

\section{THE MAIN FINDINGS AND RESULTS}

As a result, student settled on online classes, because it turned out to be convenient, since it allows her to study from home and at any time. Student also said that she/he began to learn the language exclusively for herself/himself. Student does not need to take exams or use it at work. Learning English became a kind of hobby that diversified her/his life. Student studies once a week for 80 minutes, but language classes give her pleasure; in addition, the sword of Damocles of the installation does not hang over: it is necessary! Student does not feel emotional stress either during the lesson or after it. During the week, student repeats everything that was done in the virtual classroom, listens to audio recordings, and does her/his homework.

However, if we turn to the opinion of teachers about what upsets them in working with students, and most will say that this is a kind of race that almost all students who study a foreign language get into. This often happens because they have to strictly follow a certain schedule set by the language school or courses. Their advertisements say that the courses are personalized and taught in small groups. But in many cases, once in the classroom, students focus on doing certain exercises, but not on the language itself. But the study of a language is also the study of culture, a new look at the world around us. How is this expressed? In choosing new books by English-speaking authors, new songs and performers, if you are fond of music, this is watching new films in the original language, getting to know foreign cuisine, meeting people from the countries of the target language. And these are just a few examples of how acquaintance with a foreign language occurs through culture.

Learning a foreign language should take place in parallel with the discovery of new cultural realities, a new linguistic environment. A foreign language is not just a set of new words and rules; it is a new world that allows you to master the language. And it takes time for the study of the language to take place in this direction.

This situation is common, and then many experts in the field of teaching methodology will give the following advice: in addition to lessons, you need to make the language a part of your daily life. If, for example, young people like to dance, choose videos with English-speaking performers. You can not only practice reading the lyrics, but also memorize them. If they, for example, are fond of cooking, sports, travel, painting, etc., you can always find thematic publications on media sites and television programs in English.

What is the idea behind this approach? The answer is simple: if a student is passionate about a subject, he usually tries to learn as much as possible about it. And when studying a foreign language, it becomes possible to receive information of interest in another language.

It can be recommended to learn as much as possible about the country or countries in which the language being studied is spoken. For example, if a student is interested in history, flora and fauna, monuments, cities, industry, education, tourism, etc. Also, it is important to communicate with native speakers, and for this it is not at all necessary to travel to the country of the target language, because you can find native speakers in various language and professional forums. Most importantly, you need to practice the language in a way that is not boring and that the process is not tedious.

The process of learning a language cannot depend only on the teacher, who, of course, controls the process. Much depends on your attitude towards the language and its study. It is important to remember that in order to learn a 
CURRENT RESEARCH JOURNAL OF PHILOLOGICAL SCIENCES 2(10): 36-

40, October 2021

DOI: https://doi.org/10.37547/philological-crjps-02-10-08

ISSN 2767-3758

(C)2021 Master Journals

Crossref do

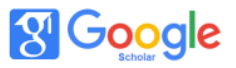

Accepted $26^{\text {th }}$ October, 2021 \& Published $31^{\text {th }}$ October, 2021

language, it is not enough to sign up for courses and attend classes. It is also not enough to convince yourself that if you do not learn a foreign language, then the prospects for the future are very deplorable. In this regard, you need to admit to yourself that language classes are not in order to replenish vocabulary and master the grammar of the language, but in order to integrate into another culture and become its carrier.

The essence of the technology is as follows: the teacher, with the help of special cognitive or problem-search tasks and instructions, helps and guides the student to the discovery of new knowledge, relying on his experience, and this support in practice can be expressed in various forms, for example, in the form of a block schemes, key or leading questions ("Socratic conversation"), recommendations, etc.

Scaffolding technology is considered by modern authors as a special type of instruction process that takes place in situations of interaction between a teacher (or other more knowledgeable source) and students in solving educational problems.

The main characteristic of a scaffolding strategy is fading help from the teacher during independent work. "Fading help" from the teacher at the beginning of training can be frequent and meaningful, and by the end of the course, it is significantly reduced or absent altogether.

The authors deduce two basic rules: to help the student in completing tasks with which he cannot yet cope; allow the student to complete such a volume or such a number of tasks that he can already cope with independently. The main characteristic, an indicator of scaffolding, is the "fading help" from the teacher's side, i. e. reducing the degree of intensity of assistance until the moment when the student becomes completely independent and autonomous. There are five main characteristics of a scaffolding strategy: intentionality of actions, appropriateness of actions, structure of actions, and cooperation in the process of completing tasks, naturalization (assimilation) of actions.

The scaffolding strategy is one of the effective interaction strategies in the course of students' independent work. The table reflects the main characteristics of the scaffolding strategy "fading help" on the part of the teacher in the course of students' independent work.

Scaffolding has several meanings, but in the context of education, it means providing support to stimulate the learning process at a time when a general understanding has already been given to the learner. Support may consist of additional assignments appropriate to the student's level, manuals, instructions, and examples. Simply put, the teacher helps the student complete the assignment and understand the concept being studied.

Close interaction of participants in the educational process, exchange of experience and an attempt to modify existing programs are three pillars on which the course is based. At the same time, great attention is paid to the interaction of students with each other and the teacher. The seminars of the course can be built in the format of live communication - discussions, where most often the material is proposed to be broken down into categories (for example, new terms can be grouped by fields of application). You can also often use the format of games: working in pairs, participants must present the material in English, after which they change places and roles.

When the student realizes that he will have to tell the material he heard immediately, this stimulates the process of understanding and memorization. Exchange of experience and modification are those sections of the course that 
CURRENT RESEARCH JOURNAL OF PHILOLOGICAL SCIENCES 2(10): 36-

40, October 2021

DOI: https://doi.org/10.37547/philological-crjps-02-10-08

ISSN 2767-3758

(C)2021 Master Journals

Crossref do

8 Google

Accepted $26^{\text {th }}$ October, 2021 \& Published $31^{\text {th }}$ October, 2021

are responsible for the analytics of the educational process. They should be given special attention, since it is important to keep track of what exactly is happening with the learning process, which is fundamentally built once and therefore runs the risk of falling into stagnation. In addition to writing reviews, program participants can modify the material. The idea of the modification is to make the course more tailored to the specifics of the audience, taking into account the problems that arise with understanding among students in the learning process.

Education as a whole should be aimed at learning to maintain the existing educational course systematically and constantly keep a finger on the pulse, to control what is happening in the process of teaching students.

Often, students lose faith in themselves, especially when they cannot cope with the tasks: they cannot remember the words, they cannot hear the speaker's speech, they cannot express themselves coherently, they write with a lot of mistakes. Students get upset and their motivation decreases. The teacher also feels responsible for the current situation and tries to find a way out.

\section{Conclusion}

How can you help the learner to believe in himself? Three simple steps can be suggested: creating a situation of success; promoting the formation of positive thinking; reinforcement of motivation with praise. When fostering positive thinking, it is important to have faith in the student's potential. Professor Carol Dwerck says that successful people have a Growth mindset: they see "success as a result of hard work", "everyone can improve their skills over time", "challenges are opportunities to grow". Students should have such ideas as well. They need to be motivated for success and encouraged, taught to perceive failure as an opportunity to learn something new. Failures often occur if the student does not pay enough attention to the class. Student studies too rarely: less than 2-3 times a week, skips classes, does not do homework, and does not practice words. The way out of this situation will be an increase either in the number of classes, their duration, or more independent work.

\section{REFERENCES}

1. Parkinson, J., Jackson, L., Kirkwood, T., \& Padayachee, V. (2007). A scaffolded reading and writing course for foundation level science students. English for Specific Purposes, 26(4), 443-461.

2. Adrian, J. A. L., Zeszotarski, P., \& Ma, C. (2015). Developing pharmacy student communication skills through role-playing and active learning. American journal of pharmaceutical education, 79(3).

3. Sin, S., Jones, A., \& Petocz, P. (2007). Evaluating a method of integrating generic skills with accounting content based on a functional theory of meaning. Accounting \& Finance, 47(1), 143-163.

4. Chao, Y. C. J., \& Lo, H. C. (2011). Students' perceptions of Wiki-based collaborative writing for learners of English as a foreign language. Interactive Learning Environments, 19(4), 395-411.

5. Schwieter, J. W. (2010). Developing second language writing through scaffolding in the ZPD: A magazine project for an authentic audience.

6. Yu, F. Y. (2009). Scaffolding studentgenerated questions: Design and development of a customizable online learning system. Computers in Human 
CURRENT RESEARCH JOURNAL OF PHILOLOGICAL SCIENCES 2(10): 36-

40, October 2021

DOI: https://doi.org/10.37547/philological-crjps-02-10-08

ISSN 2767-3758

(C)2021 Master Journals

crossref do) 80 Google

Accepted $26^{\text {th }}$ October, 2021 \& Published $31^{\text {th }}$ October, 2021

Behavior, 25(5), 1129-1138.

7. Devereux, L., \& Wilson, K. (2008).

Scaffolding literacies across the Bachelor of

Education program: an argument for a

course-wide approach. Asia-Pacific Journal

of Teacher Education, 36(2), 121-134.

8. Walton, M., \& Archer, A. (2004). The web and information literacy: Scaffolding the use of web sources in a project-based curriculum. British journal of educational technology, 35(2), 173-186.

9. Emerson, L., Rees, M. T., \& MacKay, B. (2005). Scaffolding academic integrity: Creating a learning context for teaching referencing skills. Journal of university teaching \& learning practice, 2(3), 3.

10. Veerappan, V. A., Suan, W. H., \& Sulaiman, T. (2011). The Effect of Scaffolding Technique in Journal Writing among the Second Language Learners. Journal of language teaching \& research, 2(4). 